\title{
FUNCTIONING OF ECHO-QUESTIONS IN THE PRAGMATIC SPEECH
}

\author{
Antonina Artemenko \\ Senior Lecturer, Kyiv National Economic University named after Vadym Hetman, Ukraine \\ e-mail: antoninaartemenko33@gmail.com,orcid.org/0000-0003-2426-875x
}

\section{Veronica Anawa Dashaco}

Professor, Ph.D., Polonia University in Czestochowa, Interdisciplinary Faculty, Poland e-mail: vdashaco@ap.edu.pl, orcid.org/0000-0003-4062-9826

\section{Summary}

The aim of this article is to analyze the echo-questions in the pragmatic speech. Echo-questions are the pragmatic phenomenon which have the specific features of pragmatic speech. They have cognitive and pragmatic features associated with the process of perception and understanding of the previous phrase. Echo-questions can express different feelings and emotions according to their pragmatic aspect. They can be used in the dialogue speech and have different functions, such as communicative, syntactical, structural and semantic. They can be classified into different types according to their functions. Echo-questions according to the structural and semantic aspect can be characterized as verifiable echo-questions clarifying the content of the statement. The usage of echo-question makes it possible to realize the more complex inner world of speakers. Functioning of echo-questions in the creating of simple and complex statements leads to pragmatic interaction of the speech. The research identifies three stages of syntactic development of this phenomenon which are used in the speech of speakers of different age. General scientific (analysis and synthesis, induction and deduction), method of theoretical research (from abstract to concrete) are used in this research.

Keywords: pragmatic speech, linguistic features, functions, echo-questions, speakers.

\section{DOI https://doi.org/10.23856/3902}

\section{Introduction}

Echo-questions as a specific type of interrogative sentences are used in the dialogue speech which can be divided into specific fragments - dialogue units, represented by separate phrase which are combined syntactically, semantically, situationally and pragmatically.

There are functional and semantic relations between the first and the second phrases which can have different pragmatic directions in speech.

The presence of interlocutors allows us to consider the dialogue situation as a dynamic system of two (or more) subjects that reflects their consciousness encouraging pragmatic activity in solving problems of the pragmatic speech.

Pragmatic activity is the basis of communication. It is the interest of participants of pragmatic speech where the results of pragmatic actions can stimulate the achievement of the common interests of speakers. Coordination of efforts of participants of pragmatic speech is created on the basis of cooperation (Polyakov, 1985).

The typology of echo-questions, which is proposed by researchers, is based on different principles. There are echo-questions which are on the basis of given alternatives, compliance and expectations of the speaker, realized intention. 
The increase in the intensity of research on the problem of indirect speech acts as well as increased interest in echo-questions have led to the fact that in some works there have been attempts to more systematically consider such indirect uses of echo-questions.

The usage of echo-question makes it possible to realize the more complex inner world of speakers. The reproduction of the inner world inherent in the sender takes place firstly in one object and then in his recipient. The relations reproduced in two different objects, interconnected by the needs of the consumer, are qualitatively different from each other: the reproduction of the sender's relations in the first object is aimed at transmitting the message, and in the second object is aimed at its implementation by the recipient.

\section{The communicative function of echo-questions}

The communicative function of echo-questions is to establish contact between interlocutors expressing their inner feelings, clarifying information or filling in communicative pauses which allows to have the meaningful communication. Communication, which is an abstract concept, has an appropriate set of meanings, conceptual components, one of which is the idea of it as a way of transmitting information, thoughts, emotions and skills involving the pronunciation of words based om ideas.

The transmission of messages is carried out with the participation of the sender and recipient constituting an act of pragmatic communication which can be considered as an act of interaction between speakers. We can admit that echo-questions can also be described as a direct and indirect question. In the dialogue the echo-questions are used as a pragmatic phenomenon which have the specific features of pragmatic speech. (Wunderlich, 1981) These are their cognitive and pragmatic features associated with their creation in the process of perception and understanding of the previous phrase. The dual nature of the echo-questions allows speakers to act as an incentive to continue the pragmatic speech.

Functioning of echo-questions in the creating of simple and complex statements leads to pragmatic interaction of the speech.

The using of echo-questions makes it possible to realize the inner state of speakers.

The reproduction of the inner state of the speaker takes place in one object of the echo-question and then due to the echo-questions takes place in the recipient.

The relations reproduced in two different objects, interconnected by the needs of the speakers, are qualitatively different from each other. The reproduction of the sender's relations in the first object is aimed at transmitting the message and in the second one is aimed at its implementation by the recipient (Danes, 1964).

In the next dialogue:

Horace. I was in love with you. But why did you marry me?

Regina. I was lonely when I was young.

Horace. You were lonely?

Regina. Not the way people usually mean. Lonely for all the things I wasn;t going to get. (Hellman: 211)

the echo-question You were lonely? is used to express surprise. We can admit that surprise can be conveyed by other means but the using of echo-question helps us to express this state deeply and more accurately.

In the next dialogue:

"And I said, as soon as the priest finishes."

"And the priest? 
"I don't know," I told him and I saw his face working and the sweat coming down on the forehead.

"I have never killed a man," he said. (Hemingway: 37)

the echo-question And the priest? expresses surprise too. And at the same time it is used for clarification of information.

In the next dialogue:

"Advising them in time, it should be possible to unite fifty rifles of a certain dependability". "How dependable?"

"Dependable within the gravity of the situation." (Hemingway: 65)

the echo-question How dependable? is used for clarifying of information.

In the next dialogue:

Jake: I remember how we got here.

Andy: How?

Jake: You were sitting on me, you were bending over to brush my face with your hair, and I all of a sudden knew ... (Bell:27)

the echo-question How? is used to express irritation.

In the next dialogue:

Nina: Ned does not love her - but he used to like her and, I think, desire her.

Does he, doctor?

Dares:(thinking) Does he?... Who is he?... He is Ned!... I desire her !... I desire happiness!... (Neil:545)

the echo-question Does he? is used for clarification of information.

In the next dialogue:

"What progress, man?" Galmony asked.

"Progress?"

"With the documents “, he explained.' Weren't they you gave the speed woman?" (Gibbs: 73) the echo-question progress? expresses surprise.

In the next dialogue:

Christine: Everything! I've felt your distrust from the moment you came.

Your eyes have been probing me, as if you were a judge again and I were the prisoner.

Mannon: (guiltily) I?

Christine: And all on account of a stupid letter. Vinnir had no business to write. It seems to me a late day when I am an old woman with grown-up children, to accuse me of flitting with a stupid ship captain. (O’Neil:706)

The echo-question I? expresses guiltiness.

In the next dialogue:

Sophi. Yes. I am sure. But I will not accept it as largeness - to make you happy. We will call it a loan, come by through blackmail money, nor think of oneself as a charity girl.

Nina. (after a second). Blackmail money?

Sophie. Yes ma'am. (Hellman: 485)

the echo-question Blackmail money? is used for clarification of information.

In the next dialogue:

Ruth (At the phone) Hello- Just a minute. (Goes to door)

Walter. It's Mrs. Arnold (Waits. Goes back to the phone. Tense) Hello. Yes, this is his wife speaking ... He's lying down now. Yes...well, he's be in tomorrow. He's been very sick. Yes- I know. We should have called, but we were so sure he'd be able to come in today. Yes-yes, I'm very sorry. Yes...Thank you very much (She hangs up. Walter is standing in the doorway of the bedroom behind her). That was Mrs. Arnold. 
Walter (indifferently). Was it? berry:1680)

Ruth. She said if you don't come in tomorrow that, they are getting a new man...(Hans-

the echo-question Was it? expresses indifference.

In the next dialogue:

Horace. I didn't have bad time. (As she shakes her head he becomes insistent) no, I didn't.

Regina. Oh, at first when I - when I heard the news about myself - but after I got used to that. I liked it there.

Horace. You liked it? (Coldly) Isn't that strange. You liked it so well didn't you want to come home?

echo- question You liked it? expresses restraint.

In the next dialogue:

Bess: I picture you.

Macon: What? You pictured me? (Henley: 51)

the echo-question You pictured me? which has the intensifier What? is used to express astonishment.

The next dialogue:

"Is it possible" exclaimed Mr. Lorry." Is it possible? repeated De Farge bitterly." Yes. And a beautiful world we live in, when it is possible, and when many other such things are possible, and not only possible, but done, see you! - under that sky there, every day long live the Devil. Let us go on." (Dickens:57)

contains an echo-question Is it possible? which repeats the previous remark completely and expresses bitterly state of the speaker.

The next dialogue:

"Holes?"Marie looked about her as if searching for them.

"Where is he?"

"Where's who?"

"Both well," she replied absently.

"He's the one who saved you, not I." (Gibbs: 226)

demonstrates an echo-question Where's who? which is used to clarify the information.

Thus, echo-questions can have different communicative functions which influence on the communicative process and give the opportunity to express the idea better and deeply. Echo-questions have not only communicative functions but structural and semantic ones.

\section{The structural and semantic functions of echo-questions}

The syntax of echo-questions is the result of communicative and traditional division into parts of speech. There are two tendencies in the syntactic construction of echo-questions of a simple utterance - the simplicity of the grammatical form and the preservation of lexical units that indicate grammatical relations. The first tendencies correspond to such features of echo-question syntax as relatively short length of utterances, predominance of syntactically simple sentences, using of phrases with predicative connection (mostly nouns), direct word order and etc. (Shvachko,1978)

In the next dialogue:

"This is all so foolish. Miss Speed will hold the documents in her briefcase' - she inclined her head towards Diana, in a gesture that should have looked artificial but didn't - "Mr. Pearse obviously requires to keep the papers he has. And Mr. Sarsfield can stay here..." 
"Stay here? exploded Pearse ...(Gibbs:181).

the echo-question Stay here? consists of two words.

Echo-questions as well as questions can have the intention of motivating the speaker (Strelchenko, 2017). We can admit that this phenomenon can be characterized as verifiable echo-questions that can clarify the content of the statement.

It is established that echo-questions according to the structural and semantic aspect can be characterized as verifiable echo-questions clarifying the content of the statement (Pocheptsov, 1986 :197).

In the next dialogue:

Sophie. Yes. I am sure. But I will not accept it as largeness - to make you happy. We will call it a loan, come by through blackmail money, nor think of oneself as a charity girl.

Nina (after a second). Blackmail money?

Sophie. Yes ma'am (Hellman: 485).

The verifying echo-question is used to clarify the information.

In the next dialogue:

"Father", said Maggie, laying her hand on his, "don't you remember that Mr. Riley is dead?"

"Dead?" said Mr. Tulliver sharply, looking in her face with a strange, examining glance.

"Yes, he died of approximately nearly a year ago. I remember hearing you say you had to play money for him; and he left his daughters badly off — one of them is under-teacher at Miss Firmss's, where I've been to school, you know ..." (Eliot: 311)

the verifying echo-question Dead? expresses sharpyness.

We can admit that verifying echo-question that include special and general echo-questions can be:

a) partial, those that repeat the previous statement partly.

In the next dialogue:

Ben's Voice. Uncle Willie. It's Ben.

Willie. Ben? Is that you?

Ben's Voice. Yes. Open up. (Simon: 324)

the echo-question Ben? is partial because it repeats the previous statement partly and at the same time has the pragmatic meaning and express astonishment.

In the next dialogue:

Horace. I didn't have a bad time. (As she shakes her head he becomes insistent) No, I didn't.

Regina. Oh, at first when I - when I heard the news about myself - but after I got used to that. I liked it there.

Horace. You liked it? (Coldly) Isn't that strange. You liked it so well didn't you want to come home? (Hellman: 187)

the echo-question You liked it? is partial too.

In the next dialogue:

Bess: Hunt the elephant.

Macon: The elephant?

Bess: Bang, bang, bang (Henley: 51)

the partial echo-question The elephant? expresses astonishment.

In the next dialogue:

Willy: What - what's the secret?

Bernard: What secret?

Willy: How - how did you? Why didn't he ever catch on? (Miller: 31) 
the echo-question What secret? expresses surprise and it is partial.

In the next dialogue:

"Don't you think that she's the most wonderful woman in the world?"

Said Paul.

"Wonderful? In what way?" (Waugh: 127 - 128)

the echo-question Wonderful? is partial.

b) complete, those that repeat the previous statement completely.

In the next dialogue:

Stranger: Rocks.

Woman: Rocks?

Stranger: Moonrocks. (Guyer: 103)

the echo-question Rocks? repeats the previous statement completely.

c) identifying, those that repeats the affirmative statements partially or completely.

In the next dialogue:

I don't know. I never thought of that. It costs four thousand dollars, you know.

Julie: Four thousand dollars? Where would you get four thousand dollars!? (Shepp: 36)

the echo-question Four thousand dollars? is identifying and expresses surprise.

In the next dialogue:

Lavina: (still suspiciously - with a touch of scorn) If I loved anyone - !

Christine: (tauntingly) If? I think you do love him - as much as you can love! (With a sudden flurry of jealousy) You little fool! Don't you know I made him flirt with you, so you wouldn't be suspicious?

Lavina: (gives a little shudder - then fiercely) He didn't fool me! I saw what a liar he was! I just led him on - to find out things! I always hated him!. (O’Neil: 689)

the echo-question If? Is identifying.

d) non-identifying, those that repeat non -affirmative statements.

In the next dialogue:

Alper. Well, I'll tell you Rabbi (He scowls, a little flustered, then turns and goes out of the office) Excuse me.

The Rabbi. (On the phone) Locust 6-0932.

Alper. (To Zitorsky) She's not there.

Zitorsky. She's not there?

Alper. I'll have to go out and look for her (Frowning in contemplation, Alper puts his coat on slowly and exits from the synagogue.

The Rabbi is still on the phone. His voice rises to the pitch usually used for long distance calls (Chayefsky: 54)

the echo-question She's not there? is non-identifying because it repeats the previous statement which is negative.

In the next dialogue:

Thus, according to the structural and semantic functions echo-questions can be classified into different types and express different pragmatic meanings. We can admit that echo-questions can include semantic functions too.

\section{The syntactic functions of echo-questions according to the age of speakers}

Studying of the phonological, syntactic and extra linguistic components of echo-questions taking into account the age indicators of the speakers, such as the sender of information 
and the recipient of information is actual at present time of researching this linguistic phenomenon. The research identifies three stages of syntactic development of this phenomenon which are used in the speech of the children. One-word echo-question can be used by the speaker of one year old, two-word echo-question can be used by the speaker at the age of 18 to 20 months, three-word echo-question can be used by the speaker from 20 months (Brown, 1978:63-99).

During the process of the using echo-questions by children we can see that only at the final stage the using of echo-questions by the children approaches the adult speech. Most researches who analyze a person's speech focus on developing the child's ability to use echo-questions. It is believed that the typical echo-question of a two-year-old child complicated echo-questions. Analyzing the two-component echo-questions two classes of words are identified such as the echo-questions of the "core class" and echo-questions of the "open class". In the complicated echo-questions the first element belongs to the "core class" such as predicative one and the second element belongs to the open class such as an objective echo-question.

From the linguistic point of view children under the age of 5-6 years old don't establish schemes for constructing of the dialogue speech with echo-questions. Only at the age of 6 years old they consciously use the previous echo-question to interpret the utterance, it is researched that only at the age of 9 year old children consciously distinguish promises from the prediction. (Strelchenko, 2017)

We can admit that 7-12 years old children can freely manipulate logical operations. At the period of the adolescence there is a mastering of the formal interactional and inter propositional operations that creates the basis for the widespread use in various versions of the dialogic speech with echo-questions. The foundation of the stylistic coloring of speech with using of echo-questions is formed by the children of 5-13 year old.

Five -year-old children try to use echo-questions correctly characterizing the speech pragmatically (Austin, 1975).

Semantic difficulties in using echo-questions by children are correlated with age of the perception of the certain grammatical models.

Linguistic features of the echo-questions which are determined by the age of communicators are related to the development of the communicative competence of the children. Communicative competence is a basic concept for understanding of the communication with echo-questions. The competence of the communication with echo-questions is the result of the development of their application and comprehension where the communicative competence is considered in terms of generating grammatically corrected utterance according to the rules of the application as a linguistic competence is measured on a two-dimensional scale with three degrees of the communicative competence: minimum, average and maximum (Dittmar, 1976).

The concept of the linguistic competence of the communication with echo-questions is expanded by defining of the function of communicative acts and a detailed analysis of the promises and apology. The most convincing concept is the concept of the communicative competence with echo-questions includes at least four areas of knowledge and skills: grammatical competence such as the knowledge of the linguistic code, spelling, rules of the sentence generation: sociolinguistic competence such as knowledge of the speech acts and the ability to apply them in a particular situation: discursive competence such as the ability to use communicative strategies in different genres of different communicative styles; strategic competence such as skills of the formation and operation of communication with echo-questions. (Halliday, 1967)

This research is devoted to the researching of the children speech who can use echo-questions in their dialogue speech. It shows that children under the age one year old can use one-word, two-word and three-word echo-questions. We can admit that children use echo-questions without thinking about the meaning of the echo-questions they repeat. It means that they use "unconscious 
echo-questions" in their speech. At the age of five year old children use echo-questions consciously expressing such feelings as orders, prohibitions, permission and so on.

We can admit that the frequency of using of echo-questions is influenced by the environment where the children are. If the adults use echo-questions more often the children can imitate adults using echo- questions.

At the age of nine-year old children use echo-questions consciously clarifying information and at the same time filling in communicative pause.

At the age of twelve year old children often use logical echo-questions in their dialogue speech such as they are fully aware of the intention of their speech and the echo-questions are very specific. During the adolescence children often repeat different pragmatic structures. Analyzing the dialogue speech of the older generation when the communication can be between adults and adults, children and adolescents we can admit that the dominant factor that determines the lexical and syntactical content of adults is not the level of their communicative competence but accommodation to the level competence of the child/adolescence.

We can admit that the conversation can take place between:

1) adults and children;

In the next dialogue:

"You're thick with him sometimes," said old Macy, turning on me. "Hasn't he told you all about it?"' Me? I said. "No." Mind you, the whole thing's not to be wondered at," said the old man." Front and back doors never licked, and money kept in the house. That's a terrible temptation to anyone with a weakness that way. A temptation that shouldn't have a bun put." (Pearsce:14).

The conversation takes place between neighbors. One of them is old man and the other one is a child. The child uses the echo-question $M e$ ? to express the surprise.

2) between peers-adolescents ;

In the next dialogue:

"You know Belinda Thomas skates?"

Does she?" Where? I've never seen her."

"Over at Wolverhampton - Josey Law told me - you should change rinks." (Walker: 91)

3 ) between the mother and the son;

In the next dialogue :

Tom: He's coming tomorrow.

Amanda: Tomorrow?

Tom: Yes. Tomorrow.

Amanda: Booth, Tom!

Tom: Yes, Mother. (Williams:46)

the mother uses the echo-question Tomorrow? in order to clarify the information.

4) between the mother and the daughter;

In the next dialogue:

"I suppose," she said eventually," the University will always need a warden of some kind to look after the place; even if the lottery bid doesn't come off."

"Might it not come off?"

"There are a lot of problems. There's a lot of opposition to the project because of the cost for one thing. But this is a listed building, so it can't just be allowed to fall down." (Oldham: 157) the mother is used the echo-question Might it not come off? expressing the surprise.

5) between a girl and a boy;

In the next dialogue: 
“Look”, I said, "I' ve only just arrived at Agios Georgios today, and I haven’t. "“'Agios Georgios? You've walked up from there?"

"From the bridge, yes."

"Is there a path all the way? Does it come straight here? To the hut? This was Lambus and his voice was sharp. (Steward:10)

the conversation is between the boy and the girl. The echo-question is used to express the surprise and to clarify the information.

6) between adults;

In the next dialogue :

"They're bad, sir," said the young man. But he didn't look worried; he looked pleased, proud of himself."

"That sewage works is putting a lot of nasty things into the river, you know. I think the newspapers will be very interested."

"The newspapers? John asked.

The young man smiled. "Yes. Mr.Duncan, of course. Our company cares about the environment, doesn't it? That's why we're doing this. We want to help those poor seals, If we can." (Vicary: 35)

The conversation is between adults of the same sex but different age. One speaker is young and the second is old. But they are interested in the information about the environment and seals. The echo-question The newspapers? Is used to express the joy according to this information.

7) between a brother and a sister;

In the next dialogue:

"Ah!” Said Joe." “Another convict's escaped. One of away last night.

They always fire the gun when one escapes."

"Who fires the gun? I asked. Joe shook his head to warn me.

"Too many questions, "frowned my sister," If you must know It's the men in the prison -ships who fire the gun." (Dickens :3), which is between the brother and the sister. The echo-question Who fires the gun?

8) between a lawyer and a person;

In the next dialogue:

"Please, Mr. Jaggers, 'he begged, "my brother is accused of stealing silver. Only you can save him! I'm ready to pay anything!

"Your brother?" repeated the lawyer." And the trial is tomorrow? Wen, I'm sorry for you, and him. I'm on the other side."

"Well, Mr. Jaggers!" cried the man desperately, tears in his eyes.

"Don't say you're against him! I'll pay anything!" (Dickens: 40)

Is a conversation between a lawyer and a man who wants to save his brother. But the lawyer has refused him and the echo-question Your brother? is used to express negative feelings.

9) between an old man and a policeman;

In the next dialogue:

In the anxious silence, old Jim suddenly said,"Ah! So that both policemen jumped. He had opened his eyes, and now he said, "You could tow me home."

"Tow you home? Repeated the policemen.

"Fasten my bath-chare to the back of your car with a tow -rope," said old Jim.

"Pull me home on a tow -rope." 
the conversation is between an old man named Jim and the policemen. The policemen uses the echo-question Tow you home? in order to fill the communicative pause and at the same time expresses surprise.

Thus, according to the semantic functions of echo-question the research identifies three stages of syntactic development of this phenomenon which are used in the speech of speakers of different ages.

\section{Conclusion}

Thus, echo-questions have been researched sufficiently in terms of lexical meanings and a number of typical grammatical constructions. However, not enough attention has been paid to pragmatic means of echo-questions. Therefore, from the point of view of the theory of modern communicative semantics the further research of the functioning of echo-questions in the pragmatic speech is required. Its consideration in the unity of the grammatical, lexical, phonetic and pragma linguistic means are taking into account situational factors and personal characteristics of the speakers. This allows ultimately allow us to research echo-questions in term of the functions they perform in the communicative process.

\section{References}

Austin J. L. (1962) How to do things with words. - Oxford. [In English]

Brawn G., Levinson S. (1978) Universals in language use: politeness phenomena //Questions and Politeness. Strategies in social interaction. Cambriadge. [in English]

Danes F. A. (1964) Three level approach to syntax//Travaux Linguistiques de Prague, I.-Praha. [in English]

Dittmar N. (1976) Sociolinguistics. - London: Edward Arnold LTD. [in English]

Halliday M. (1967) Notes on transitivity and theme in English//Journal of Linguistics. [in English]

Polyakov S. M. (1985) Slozhnoye dialogicheskoye yedinstvo s odnostoronnyej organizatsiyej (na materialye sovrem.ang.yaz.)[Complex dialogical unity (based on the material of the modern English]. M. [in Russian]

Pocheptsov G. G. (1986) O kommunikativnoj tipologii adresata v lingvistikye i metodikye [About communicative typology of addressee in linguistics and methodology]. Pyatigorsk. [in Russian] Shvachko C. A. (1978) Yazykovyye sredstva vyrazheniya kolichestva v sovremennom anglijskom, russkom i ukrainskom yazykakh[Language resources of expressing strategies in social interaction]. Cambridge. [in Russian]

Strelchenko, N (2017) Echo questions as a means of building coherence in conversational discourse. Warsaw. [in English]

Wunderlich D. (1981) Questions about questions // Crossing the boundaries in linguistics. Dordrecht. [in English] 